УДК 378.14

Н. В. Гонгало,

аспірант

(Вінницький державний педагогічний університет імені Михайла Коцюбинського) nataliiahonhalo@gmail.com

ORCID: 0000-0002-1183-7215

\title{
АНАЛІЗ ЗАРУБІЖНОГО ДОСВІДУ ВДОСКОНАЛЕННЯ УМОВ ФАХОВОЇ ПІДГОТОВКИ МАЙБУТНІХ ГЕОДЕЗИСТІВ
}

Проведено аналіз програм професійної підготовки майбутніх фахівиів в області геодезії, землеустрою та картографії на прикладі університетів розвинутих країн: Франиії, Швеції, Німеччини, Австрії,

Великобританії. Здійснено уточнення основних вимог до абітурієнтів зазначених напрямків та тривалість підготовки студентів на здобуття освітніх ступенів "Бакалавр" $i$ "Магістр" в галузі геодезії. Схарактеризовано основні иілі $і$ завдання освітніх програм в підготовиі інженерів геодезичних спеиіальностей. Проаналізовані навчальні плани підготовки майбутніх фахівиів, умови проходження навчально-виробничих практик.

Ключові слова: геодезія та землеустрій, інженерна освіта, компетентнісний підхід, професійні компетентності, освітні програми.

Постановка проблеми. Розвиток соціально-економічних систем України відбувається в безпосередньому взаємозв'язку з світовими тенденціями, які стосуються усіх сфер людської діяльності. Особливої значущості набуває процес вивчення зарубіжного досвіду організації педагогічних програм підготовки майбутніх фахівців 3 метою надання якісної освіти в умовах компетентнісного підходу. Це стосується будь-яких спеціальностей, зокрема й інженерних.

Геодезист - це перш за все інженер, який пройшов підготовку і навчання в спеціалізованих ВН3. Геодезист займається нанесенням на папір або електронний носій координат об'єктів на місцевості, або навпаки вказує місце розташування об'єктів згідно з проектними даними. Робота геодезиста полягає в зіставленні і зв'язку картографічних даних 3 реальним розташуванням досліджуваних об'єктів. Геодезистами можуть працювати інженери-геодезисти, топографи, інженери-землевпорядники, маркшейдери, кадастрові інженери і т.д. Всі ці назви просто вказують на конкретний вид діяльності геодезиста. Фактично це може бути одна людина, яка володіє необхідними навичками роботи.

Згідно наказу МОН України [1], спеціальність 193 "Геодезія та землеустрій" належить до переліку спеціальностей галузі знань "Архітектура та будівництво". Студенти, які стануть фахівцями $з$ даної спеціальності зможуть обіймати посади інженера-геодезиста, інженера-землевпорядника, картографа, фотограмметриста тощо. Безумовно, до майбутніх інженерів, які навчаються за спеціальністю "Геодезія та землеустрій" висуваються нові вимоги до якості їх професійної підготовки у вищих навчальних закладах України.

Мета даної статті - проаналізувати умови фахової підготовки майбутніх інженерів геодезичних спеціальностей розвинених західноєвропейських країн з метою використання закордонного досвіду в удосконаленні геодезичної освіти в Україні.

Аналіз останніх досліджень і публікацій. Досвід закордонної підготовки інженерів вивчали багато дослідників, зокрема, М. І. Михайлюк (зарубіжний досвід професійної підготовки інженерів в області наноелектроніки) [2], Л. Д. Герганов (досвід професійної підготовки кваліфікованих робітників на виробництві), О.А. Стахова (функціювання системи підготовки фахівців у технічних коледжах), Л. А. Кукушкіна (вимоги до фахівців інженерного профілю в Німеччині) [3] та інші. Світовий досвід підготовки картографів-геодезистів та його використання в розвитку географічної освіти в Україні висвітлено в роботі В. В. Тишковець, В. М. Опара [4]. Аналіз опублікованих праць дозволяє стверджувати, що технології і методики підготовки сучасного інженера мають загальний характер і 3 успіхом можуть використовуватися в практиці підготовки інженерів спеціальності "Геодезія та землеустрій".

Виклад основного матеріалу. Сучасне виробництво очікує від випускників ВНЗ не тільки високих теоретичних знань, а і сформованих професійних навичок та умінь, які необхідні в професійній діяльності в складних умовах конкуренції. Головним завданням вищої інженерної освіти $є$ формування професійних компетентностей майбутніх фахівців з урахуванням потреб як вітчизняних підприємств, так і зарубіжних компаній. У зв'язку з цим значний інтерес представляє зарубіжний досвід розвинених країн з удосконалення умов фахової підготовки інженерів, де вища освіта має новітні наукові досягнення та розробки. Розглянемо основні аспекти підготовки геодезистів у розвинутих європейських країнах.

Геодезичні та пов'язані з ними організації, як і в більшості країн, у Франції діляться на чотири типи груп: професійні асоціації (PA); торгові асоціації (ТП); наукові товариства (LS); зонтичні організації (UA). 
Наприклад, професійна асоціація OGE (Ordre des Géometres-Experts) налічує близько 2100 членів. Членство можливе тільки для геодезистів, які отримали диплом уряду (Diplôme Par Le Gouvernement (DPLG)), або для інженерів, які закінчили ESGT (Ecole Supérieure des Géometres et Topographes), ENSAIS (Ecole Nationale des Arts et Industries de Strasbourg) або ESTP (Ecole Spéciale des Travaux Publics, private), після 3-х років професійної практики під контролем OGE [5; 6].

Нова політика щодо освіти OGE геодезистів пов'язана з закриттям Інституту де Topométrie в 1993 році. Асоціація приймає, в основному, інженерів, які закінчили один з ВН3 ESGT, ESTP або ENSAIS та двох років практичного навчання.

Вища школа геодезистів і топографів (ESGT) створена в 1946 році у Національній Консерваторії мистецтв і ремесел (CNAM), вона є єдиною французькою установою, яка могла запропонувати реальний досвід у галузі технічних і юридичних наук на рівні магістра. 3 моменту свого створення, школа підготувала близько 3000 інженерів. Вища школа надає студентам ультрасучасні засоби вимірювання (GNSS приймачi, тахеометри, цифрові фотограмметрійні станції, 3D лазерні сканери, дрон) обробки інформації та комунікації з багатьох професійних програм (CAD, візуалізація, StereoVision, ГIC).

Підготовка фахівців першого ступеня вищої освіти (бакалаврат) в ESGT триває п’ять років. ESGT вибирає 80 студентів: близько 40, які закінчили технічні коледжі з топографії (серед 200 кандидатів з 12 коледжів), і 40 з дипломами DEUG з математики та фізики (DEUG - національний диплом про вищу освіту, який видається в університеті після перших двох років бакалаврату) або з CPGE (підготовчі класи інженерних шкіл). Навчання поділене на сім триместрів теоретичної підготовки, дві десятитижневі літні практики та п'ять з половиною місяців академічної практики після закінчення курсу (Travaux де Fin d'Etudes(TFE)). Практика проводиться в компаніях або лабораторіях i $\epsilon$ прикладною науководослідницькою роботою. Більшість лекцій в ESGT викладаються професійними геодезистами, фахівцями конкретних напрямків, інші викладачі: професори, доценти i асистенти, відбираються за університетським критерієм.

ESTP і ENSAIS мають невелику кількість студентів, які в майбутньому набудуть фаху геодезиста (від 25 до 30 студентів кожен). В ESTP навчання триває 8 триместрів 3 академічною трьохмісячною практикою. ENSAIS пропонує практики, які можуть тривати до одного року. ESTP вибирає студентів тільки з початкових інженерних шкіл і має власну школу теж. ENSAIS також вибирає студентів, в основному, з інженерних шкіл, а також, близько 10 студентів $з$ топографічних секцій.

Аналізуючи навчальні плани вказаних французьких закладів, слід відмітити, що пріоритетними науковими дисциплінами в підготовці геодезистів $\epsilon$ математичні дисципліни, земельний кадастр, кадастр населених пунктів, картографія, ГІС-технології, геодезія та право.

y ESGT, ESTP або ENSAIS, студенти можуть отримати освітні гранти (як і в будь-якому французькому університеті) за умови, що вони із малозабезпечених родин. У процесі навчання студенти повинні виїжджати за кордон на стажування або академічний обмін протягом семестру.

У Швеції виокремлено три рівні геодезичної освіти: технічний спеціаліст, бакалавр та магістр. Навчання геодезистів триває 4,5-5 роки. Підготовка ведеться в Королевському технологічному інституті (Royal Institute of Technology, KTH) в Стокгольмі (110 студентів на рік) та в Технологічному університеті Лулео (30 студентів на рік). КТН спеціалізується в області техніки і технології та займає найвище місце в північній континентальній Європі в своїх академічних областях [7]. Через нестачу місця в Стокгольмі студенти частково навчаються два роки в Гаавле в університетських коледжах, після чого навчання продовжується в КТН (30 студентів на рік). Інженери-геодезисти, які отримали освіту в коледжах впродовж 2-3 років, зазвичай, займаються зйомкою та картографією та працюють в державному, муніципальному, або приватному секторі.

У Королевському технологічному інституті студенти спеціалізуються приблизно через п'ять років у будь-якому 3 п'яти секторів: землеустрій та картографія (20), землеустрій та управління (30), економіка нерухомості та будівництва (60), регіональне планування (10), інженерна екологія (20).

Кожна 3 вище перерахованих програм закінчується індивідуально обраним проектом, який має відношення до спеціалізації. Зазвичай студенти працюють парами за обраним проектом та подають єдиний звіт, який захищають перед комісією.

Професійна практика, яка відповідає освіті в галузі регіонального планування та інженерної екології, не проводиться, так як ці спеціальні учбові програми не працюють достатньо довго.

3 геодезистів, які зайняті державою, біля 440 знаходяться в рамках Національного земельного огляду, який відповідає за кадастрову діяльність, національне картографування та національну геодезичну зйомку. Біля 40 землевпорядників $є$ дослідниками та викладачами закладів, які займаються дослідженнями та освітою.

Підготовку інженерних кадрів у Німеччині можна проаналізувати на прикладі Ганноверського університету імені Лейбніца (Leibniz Universität Hannover) [8]. Університет заснований в 1831 році. Нині в ньому навчається більше 25000 студентів у галузі природничих, технічних, гуманітарних та соціальних наук, а також, права та економіки. 
Бакалаврів за спеціальністю геодезія та геоінформатика в університеті готують 6 семестрів (3 роки). У перших семестрах необхідно здобути грунтовні знання 3 математики, фізики, інформатики, геоінформатики, геодезії і статистики, також вивчають мови програмування, основи систем баз даних і обробки цифрових зображень. Пізніше, додаються спеціальні предмети, такі як навігація або дистанційне зондування, моніторинг змін навколишнього середовища від повітряних і супутникових знімків. Заняття проводяться тільки професорсько-викладацьким складом університету.

Сучасні методи дослідження та досвіду набуваються безпосередньо в аудиторіях на семінарах, у процесі підготовки проектів і бакалаврських дисертацій. Студентам дається можливість спеціалізуватися і встановлювати пріоритети, не обмежуючи майбутні рамки кар'єри.

Для того, щоб задовольнити різноманітні сфери обов'язків і постійні зміни вимог і методів, курси зі спеціальності геодезія та геоінформатика мають великий діапазон предметів. Проекти та семінари розроблені таким чином, щоб забезпечити умови формування і розвитку ключових компетентностей, таких як робота в команді, проблемно-орієнтована діяльність. Знання та навички, які вимагатимуть при вступі на геодезичні спеціальності для абітурієнтів, відображають вміння працювати 3 комп'ютерами і зацікавленість в математичних і наукових дослідженнях.

Для бакалавра обов'язкове восьмитижневе стажування в державній або приватній установі в галузі геодезії та геоінформатики (наприклад, інспектором реєстрації землі).

Магістерські програми тривають чотири семестри. Студенти працюють незалежно один від одного із науково-дослідницькими та прикладними задачами в промисловості або в науково-дослідних установах. Грунтуючись на обов'язкових модулях в геодезії та геоінформатиці, студенти можуть спеціалізуватися в одній або декількох предметних галузях. Дисципліни довільного вибору студенти можуть обирати 3 повного діапазону курсів університету, в тому числі мають змогу повторно вивчати математичні дисципліни і програмування.

Вступ на магістерські програми з геодезії та геоінформатики можливий тільки після закінчення бакалаврату спорідненої спеціальності. В центрі уваги магістерської програми є конкретні аспекти поточних досліджень і їх практичного поглиблення на основі відібраних проектів.

У віденському технологічному університеті (TUW) (Австрія) підготовка інженерів 3 геодезії та геоматики на бакалавраті триває як і в Німеччині шість семестрів [9]. Освітню програму пропонують для абітурієнтів з глибокими знаннями в області математики, фізики та інформаційних технологій. Навчальний план характеризується поглибленими науковими аспектами, сильним практичним акцентом і міждисциплінарною спрямованістю. Вступні лекції з базових дисциплін необхідні для подальшого обрання студентами одного з курсів: вимір і земельний кадастр, геодезія і геофізика, геоінформатики та картографії. Навчальні плани в підготовці інженерів з геодезії та геоматики за бакалаврською програмою розраховані на 180 кредитів, які розподіляються між базовими та вибірковими дисциплінами. Серед базових модулів є математика (Modul Mathematik (Pflicht)) і геометрія (Modul Geometrie (Pflicht)), на ï вивчення виділено п'ятнадцять та п’ять кредитів відповідно. Починаючи з другого курсу студенти вивчають прикладну математику (Angewandte Mathematik) в об'ємі десять кредитів, яка також відноситься до обов'язкових модулів. Основні розділи модуля "Математика": лінійна алгебра, аналітична геометрія, математичний аналіз, диференціальне числення, ряди. Модуль "Геометрія" включає вивчення систем координат, елементів нарисної геометрії. "Прикладна математика" формує математичну компетентність майбутніх фахівців, відточує "математичні навички до рівня зрілості". Серед задач, які мають розв'язувати студенти - визначення координат точки на земної поверхні та перетворення систем координат.

Магістерська програма $з$ геодезії та геоінформаційних технологій триває чотири семестри та налічує 120 кредитів. Чотири кредити виділено на модуль "Додаткова математика" (Ergänzende Mathematik), розділи якої містять чисельну та дискретну математику.

У вимогах до вступу в магістру за спеціальністю "Геодезія та геоінформатика" є умова закінчення технічної програми бакалаврату.

Одним з кращих університетів Великобританії, де готують фахівців з геодезії є Університет Східного Лондону (University of East London (UEL)) [10]. Це один з двох університетів, які пропонують освітню програму бакалаврату за спеціальністю "Геодезія та картографія", яка триває три роки. Загальна кредитна оцінка цієї програми складає 360 кредитів. Навчання за програмою можливе за двома формами: перша складає 3 роки на повний робочий день (денна форма), друга - 6 років на неповний робочий день. В рамках програми дозволяється переходити з однієї форми навчання на іншу. Студент не може нормально продовжувати навчання за програмою після 4 років навчання, на протязі повного робочого дня, якщо не має виключних обставин. Навчання за програмою в режимі неповного робочого часу складає 8 років 3 моменту першого зарахування. За денною формою навчання навантаження студента складає 120 кредитів в академічному році, які містять 30 кредитних модулів. Студент, який навчається за сумісництвом, може реєструватися на вивчення до 90 кредитів в будь-який навчальний рік. 
Для можливості обрати освітню програму з геодезії абітурієнти повинні отримати при вступі оцінки рівня A2, у крайньому разі, з двох предметів, та мати розширений диплом GCSE (Certificate of Secondary Education). Рівень знань англійської мови та математики передбачається не нижче рівня С. До здачі GCSE підготовка триває 2 роки. Цей термін відведено на вивчення певних предметів, які обираються довільно. Два 3 них є обов'язковими: англійська мова та математика. Отримання сертифікату GCSE $\epsilon$ обов'язковою умовою вступу на бакалаврські програми.

Освітня програма включає різноманіття дисциплін, які характеризуються основною темою вимірювання просторових даних. Студенти мають доступ до всього спектру професійного геодезичного обладнання і програмного забезпечення, використовують його протягом усього свого навчання.

Навчання здійснюється за допомогою лекцій, семінарів, проблемного навчання та лабораторних занять. Більш ніж половина модулів, що вивчаються (як мінімум 50 \% часу навчання), завершуються в польових практичних або лабораторних класах. Робота в групах також заохочується в багатьох модулях. Регулярно проводяться відвідування об'єктів поточного будівництва. Способи оцінки варіюються від модуля до модуля, але включають іспити, курсову роботу, роботу за проектом, лабораторні звіти, презентації і тести компетентності на практичних заняттях. Студентам рекомендується розглянути можливість стажування під час їх академічної програми, або під час літніх канікул.

Стандарт програми 3 підготовці майбутніх геодезистів контролюється, у крайньому разі, одним зовнішнім екзаменатором. В обов'язки зовнішніх екзаменаторів входять: затвердження екзаменаційних документів / завдань; відвідування оціночних комісій; рецензування зразків роботи студентів і корекція оцінок; забезпечення дотримання правил; забезпечення зворотного зв'язку через щорічний звіт, який дозволяє вносити поліпшення для майбутнього. Зовнішні звіти екзаменаторів програми розташовані в віртуальному навчанні UEL.

Висновки. На основі аналізу освітніх програм зарубіжних ВНЗ розвинутих європейських країн, досвіду їх підготовки майбутніх геодезистів, можна зробити наступні висновки:

- Терміни навчання майбутніх фахівців в різних країнах відрізняються. Так, у Франції магістерську освіту можливо отримати за повних 6 років, у Німеччині та Австрії за 5 років.

- Вступ на магістерські програми з підготовці геодезистів можливий тільки за умови закінчення бакалаврату спорідненої спеціальності.

- Значна кількість годин відводиться для надання фундаментальних знань 3 математичних дисциплін та формування математичної компетентності студентів. Математична грамотність $є$ однією 3 вимог при вступі на геодезичні спеціальності (Франція, Німеччина, Австрія).

- Для надання практичних навичок університети оснащені лабораторіями, в яких сучасне обладнання та засоби вимірювання. Часто до викладання спеціальних дисциплін залучаються фахівці 3 виробництва. Так, у Франції більшість лекцій викладається професійними геодезистами.

- Формування професійних компетентностей відбувається при вивченні спеціальних та прикладних математичних дисциплін, а також обов'язкового проходження достатньої кількості годин навчальної та виробничої практики.

- $\quad$ Під час навчання в магістратурі студентами проводиться багато науково-дослідницької роботи за різними напрямами. Можливість залучитися до викладацької діяльності вимагає проходження педагогічних курсів та педагогічних практик.

Аналіз закордонного досвіду вдосконалення умов фахової підготовки майбутніх геодезистів можуть бути корисним для вдосконалення освітніх програм підготовки вітчизняних геодезичних кадрів та у забезпеченні сталого розвитку вищої інженерної освіти в цілому в рамках компетентнісного підходу.

\section{СПИСОК ВИКОРИСТАНИХ ДЖЕРЕЛ ТА ЛІТЕРАТУРИ}

1. Наказ МОН України від 06.11.2015 № 1151 "Про особливості запровадження переліку галузей знань i спеціальностей, за якими здійснюється підготовка здобувачів вищої освіти, затвердженого постановою Кабінету Міністрів України від 29 квітня 2015 року № 266" [Електронний ресурс]. - Режим доступу: http://old.mon.gov.ua/files/normative/2016-01-18/4636/nmo-1151.pdf.

2. Михайлюк М. Зарубежный опыт прфессиональной подготовки инженеров в области наноэлектроники (на примере Великобритании) / М. Михайлюк // Порівняльна професійна педагогіка № 2 (4), 2012 : [наук. журнал] / голов. ред. Н. М. Бідюк. - К.-Хмельницький : ХНУ, 2012. - 231 с. - С. 181-186.

3. Кукушкіна Л. А. Сучасні вимоги до фахівців інженерного профілю в Україні та Німеччині в контексті інтеграції / Л. А. Кукушкіна // Педагогічний альманах : [збірник наукових праць] / редкол. В. В. Кузьменко (голова) та ін. - Херсон : КВНЗ "Херсонська академія неперервної освіти", 2014. - Випуск 23. - С. 163-168.

4. Тишковець В. В. Використання світового досвіду підготовки картографів-геодезистів для сталого розвитку вищої географічної освіти в Україні / В. В. Тишковець, В. М. Опара // Проблеми безперервної географічної освіти і картографії : [збірник наукових праць]. - Харків, 2014. - Випуск 20. - С. 126-129.

5. Школа геометрів та топографів [Електронний ресурс] - Режим доступу : http://www.esgt.cnam.fr/.

6. Страсбургська Національна школа мистецтв і промисловості [Електронний ресурс]. - Режим доступу: http://www-ensais.u-strasbg.fr/.

7. Королівський технологічний інститут [Електронний ресурс] - Режим доступу : https://www.kth.se/en. 
8. Ганноверський університет ім. Лейбніца [Електронний ресурс] - Режим доступу: https://www.unihannover.de/.

9. Віденський технологічний університет [Електронний ресурс] - Режим доступу : https://www.tuwien.ac.at/en/.

10. Університет Східного Лондона [Електронний ресурс] - Режим доступу : http://www.uel.ac.uk/.

\section{REFERENCES (TRANSLATED \& TRANSLITERATED)}

1. Nakaz MON Ukraini vid 06.11.2015 № 1151 "Pro osoblivosti zaprovadzhennia pereliku galuzei znan' i spetsial'nostei, za yakymy zdiisniutsia pidgotovka zdobuvachiv vishchoi osvity, zatverdzhenogo postanovoiu Kabinetu Ministriv Ukraini vid 29 kvitnia 2015 roku № 266" [On the Characteristics of Implementation of the List of Branches of Specialties, which Provide Preparation of Higher Education Graduates, Approved by the Cabinet of Ministers of Ukraine from 04.29.2015 № 266] [Electronnyi resurs]. - Rezhym dostupu : http://old.mon.gov.ua/files/ normative/2016-01-18/4636/nmo-1151.pdf.

2. Mikhailuk M. Zarubeznyi opyt professional'noi podgotovki inzenerov $\mathrm{v}$ oblasti nanoelektroniki (na primere Velikobritanii) [Foreign Experience of Professional Preparation of Engineers in the Field of Nanoelectronics (on the Example of the UK)] / M. Mikhailuk // Porivnial'na profesiina pedagogika № 2 (4), 2012 [Comparative Professional Pedagogics] : [nauk. zhurnal] / golov. red. N. M. Bidiuk. - K. - Khmelnitskii : KHNU, 2012. - 231 s. - S. 181-186.

3. Kukushkina L. A. Suchasni vymogi do fakhivtsiv inzenernogo profiliu $\mathrm{v}$ Ukraini ta Nimechchyni v konteksti integratsii [Modern Requirements for Engineering Specialists in Ukraine and Germany in the Context of Integration] / L. A. Kukushkina // Pedagogichnyi almanakh [Pedagogic Journal]: [zbirnyk naukovykh prats'] / redcol. V. V. Kuzmenko (golova) ta in. - Kherson: KVNZ "Khersons'ka academiia neperervnoi osvity", 2014. Vypusk 23. - S. 163-168.

4. Tyshkovets V. V. Vykorystannia svitovogo dosvidu pidgotovky kartografiv-geodezystiv dlia stalogo rozvytku vishchoi geografichnoi osvity v Ukraini [Usage of World Experience in the Preparation of Surveyor Cartographers for the Continuous Development of Geographic Education in Ukraine] / V. V. Tishkovets, V. M. Opara // Problemy bezperervnoi geografichnoi osvity і кartografii [Problems of Continuos Geographic Education and Cartography] : [zbirnyk naukhovykh prats']. - Kharkiv, 2014. - Vypusk 20. - S. 126-129.

5. Shkola heometriv ta topohrafiv [School of Geometers and Topographers] [Electronnyi resurs]. - Rezhym dostupu : http://www.esgt.cnam.fr/.

6. Strasburgs'ka Natsional'na shkola mystetstv [National School of Arts and Industries of Strasbourg] [Electronnyi resurs]. - Rezhym dostupu : http://www-ensais.u-strasbg.fr/.

7. Korolivs'kyi tekhnologichnyi instytut [Royal Institute of Technology] [Electronnyi resurs]. - Rezhym dostupu : https://www.kth.se/en.

8. Hannovers'kyi universytet im. Leibnitsa [Leibniz University of Hanover] [Electronnyi resurs]. - Rezhym dostupu : https://www.uni-hannover.de/.

9. Videns'kyi tekhnologichnyi universytet [Vienna University of Technology] [Electronnyi resurs]. - Rezhym dostupu : https://www.tuwien.ac.at/en/.

10. Universytet Ckhidnogo Londona [University of East London, UEL] [Electronnyi resurs]. - Rezhym dostupu : http://www.uel.ac.uk/.

\section{Гонгало Н. В. Анализ зарубежного опыта совершенствования условий профессиональной подготовки будущих геодезистов.}

Проведен анализ программ профессиональной подготовки будущчих специалистов в области геодезии, землеустройства и картографии на примере университетов развитых стран: Франции, Швеции,

Германии, Австрии, Великобритании. Осуществлено уточнение основных требований к абитуриентам указанных направлений и продолжительность подготовки студентов на получение образовательных степеней "Бакалавр" и "Магистр" в области геодезии. Охарактеризованы основные цели и задачи

образовательных программ в подготовке инженеров геодезических специальностей. Проанализировань учебные планы подготовки будущих специалистов, условия прохождения учебно-производственных практик.

Ключевые слова: геодезия и землеустройство, инженерное образование, компетентностный подход, профессиональные компетентности, образовательные программы.

\section{Honhalo N. V. Foreign Experience Analysis of Improving Conditions of Professional Preparation of Future Geodesists.}

The analysis of programs for future specialists' professional training in the field of geodesy, land management and cartography have been analyzed on the example of universities of developed countries such as France,

Sweden, Germany, Austria, Great Britain. The basic requirements for the applicants to the indicated specialties have been clarified. The main specialties are the knowledge of Mathematics and English at a high level. The duration of preparation of students for obtaining the Bachelor's and Master's degrees in the field of geodesy has been determined. The article defines the main goals and objectives of educational programs in the training of geodetic engineers. The article also characterizes the training curricula for future specialists; identifies the 
prioritized disciplines including mathematical disciplines, land cadastre, cadastre of populated areas, cartography, GIS technologies, geodesy and law. The article studies the possibilities and conditions of educational and industrial internships; attracting students to foreign internships; the possibility for student exchange programs. The article considers the possibilities of carrying out the students' research activities, as well as the possibility of attracting graduates of master's programs to pedagogical activity with the help of pedagogical internships. The main approaches to the formation of professional competence of future specialists are determined. The article shows the possibilities of using positive foreign experience of future surveyors' professional training in national higher educational establishments.

Key words: Geodesy and Land Management, Engineering Education competitive approach, professional competence, curricula, educational and industrial practices, fundamental discipline. 